\title{
Description of Cystodiscus elachistocleis sp. nov. (Cnidaria: Myxosporea) parasitizing the gallbladder of Elachistocleis cesarii from Brazil, based on morphological and molecular analyses
}

Diego Henrique Mirandola Dias VIEIRA ${ }^{\circledR 1, *}$, Letícia PEREIRA ÚNGARI ${ }^{\circledR 2}$, Edna Paulino DE ALCANTARA ${ }^{\circledR 3}$, Enzo EMMERICH ${ }^{4}$, André Luiz QUAGLIATTO SANTOS ${ }^{\circ 5}$, Lucia Helena O’DWYER ${ }^{\circledR 6}$ \& Reinaldo José DA SILVA ${ }^{\circledR 7}$

1,2,3,4,6,7 São Paulo State University (UNESP), Institute of Biosciences, DBBVPZ, Section of Parasitology, Rua Professor Doutor Antônio Celso Wagner Zanin 250, Botucatu, São Paulo 18618-689, Brazil.

${ }^{5}$ Laboratório de Ensino e Pesquisa em Animais Silvestres, Faculdade de Medicina Veterinária, Universidade Federal de Uberlândia, Minas Gerais, Brazil.

*Corresponding author: diegovieira.50@gmail.com

${ }^{2}$ Email: letspungari@hotmail.com

${ }^{3}$ Email: ednnapaulinos@gmail.com

${ }^{4}$ Email: enzo emmerich@hotmail.com

${ }^{5}$ Email: quagliatto.andre@gmail.com

${ }^{6}$ Email: lucia.odwyer@unesp.br

7Email: reinaldo.silva@unesp.br

\footnotetext{
${ }^{1}$ urn:1sid:zoobank.org:author:89297795-FDD3-40E5-8658-D5A15EADD535

${ }^{2}$ urn:lsid:zoobank.org:author:CB714126-46D6-4D5B-BCA9-AE04AD47DA04

${ }^{3}$ urn:lsid:zoobank.org:author:688931CF-0846-4C21-93BE-F9832B40FA6E

${ }^{4}$ urn:lsid:zoobank.org:author:3C9F80E1-75A2-48A1-8576-5C287B4F1F26

${ }^{5}$ urn:lsid:zoobank.org:author:659B987A-E16C-4947-8A18-408E99256ADD

${ }^{6}$ urn:lsid:zoobank.org:author:501B3588-C93B-485D-ACAD-E0C4D9ED2ED2

${ }^{7}$ urn:lsid:zoobank.org:author:419D6833-6175-48BE-B371-65878984C032
}

\begin{abstract}
Numerous pseudoplasmodia containing myxospores belonging to the genus Cystodiscus were found in the gallbladder of Elachistocleis cesarii from Mato Grosso State, Brazil. Herein, we describe Cystodiscus elachistocleis sp. nov., using morphological and small subunit ribosomal DNA sequences. The mature myxospores were ellipsoid to ovoid, measuring in average $10.6(9.8-11.2) \mu \mathrm{m}$ in length and $6.2(5.6-6.6) \mu \mathrm{m}$ in width. Polar capsules were pyriform and equal in size measuring in average $3.6(2.8-4.3) \mu \mathrm{m}$ in length and $2.6(2.2-3.1) \mu \mathrm{m}$ in width. Polar filaments had 2-4 coils. The myxospores had 3-5 transverse ridges. The phylogenetic analysis showed Cystodiscus elachistocleis sp. nov. as a sister species of Cystodiscus cf. immersus 1 , in a subclade formed by species that parasitize the amphibians gallbladder. This is the first species of Cystodiscus described parasitizing a species of Elachistocleis and the third species of Cystodiscus described in Brazil.
\end{abstract}

Keywords. Elachistocleis, frog, phylogeny, Microhylidae, Myxidiidae. 
Vieira D.H.M.D., Pereira Úngari L., de Alcantara E.P., Emmerich E., Quagliatto Santos A.L., O’Dwyer L.H. \& da Silva R.J. 2021. Description of Cystodiscus elachistocleis sp. nov. (Cnidaria: Myxosporea) parasitizing the gallbladder of Elachistocleis cesarii from Brazil, based on morphological and molecular analyses. European Journal of Taxonomy 775: 107-118. https://doi.org/10.5852/ejt.2021.775.1549

\section{Introduction}

Myxozoans are cnidarians parasites with a complex life cycle (Lom \& Dyková 2006). Lutz (1889) proposed the genus Cystodiscus Lutz, 1889 to accommodate Cystodiscus immersus Lutz, 1889 based on a large disc-like appearance found in the amphibious gallbladder. The genus was abandoned and classified as a synonym of Myxidium Bütschli, 1882; however, Hartigan et al. (2012), performing phylogenetic molecular analyses, reerected the genus Cystodiscus as a monophyletic group instead of the polyphyletic nature of Myxidium. They have a global distribution and are endoparasites of a great diversity of amphibian hosts (Hartigan et al. 2012a, 2012b, 2016).

Cystodiscus spp. could be pathogenic but some hosts do not show pathological signs and release myxospores over time without any impact on the health of their hosts (Hartigan et al. 2012b). In pathogenic cases, the hosts may show inflammation in the nervous tissue leading to behavioral changes and even spontaneous death. Also, in cases of liver diseases, they can cause inflammation and hyperplasia, affecting the metamorphosis of tadpoles, as well as metabolism and immune function (Hartigan et al. $2012 b$ ). Due to its pathogenic potential, the parasite can have an important ecological impact on the conservation of amphibians (Hartigan et al. 2012c).

Microhylidae Günther, 1858 is one of the most diverse families of extant amphibians, distributed across most of the tropics (Frost 2020). Three subfamilies of microhylids are recognized: Adelastinae Peloso, Frost, Richards, Rodrigues, Donnellan, Matsui, Raxworthy, Biju, Lemmon, Lemmon \& Wheeler, 2016, Gastrophryninae Fitzinger, 1843, and Otophryninae Wassersug \& Pyburn, 1987 (de Sá et al. 2012; Peloso et al. 2014). Elachistocleis Parker, 1927 (subfamily Gastrophryninae) is a genus of microhylid frogs widespread distributed with 19 species, most of which occur east of the Andes in South America (Frost 2020; Sánchez-Nivicela et al. 2020). In Brazil, 12 species of Elachistocleis were reported (Segalla et al. 2019). Elachistocleis cesarii (Miranda-Ribeiro, 1920), an endemic species in Brazil, occurs from southeastern to central Brazil in eastern São Paulo, south-central Minas Gerais, Goiás, and Mato Grosso States (Toledo et al. 2010; Frost 2020). This species has sexual dimorphism and females are larger than males. They have a fossorial habit, spending most of the year sheltered under the ground, and have a marked pattern of seasonal activity (Toledo et al. 2010). This species is not on the International Union for Conservation of Nature (IUCN) red list of endangered animals.

During a study on the biodiversity of anuran parasites in Mato Grosso State, Brazil, pseudoplasmodia containing myxospores morphologically consistent with Cystodiscus were observed in the gallbladder of E. cesarii. The present study aims to describe this new species of Cystodiscus parasitizing E. cesarii from Brazil, based on morphological and molecular analyses, thus increasing the knowledge of Brazilian anurans parasites.

\section{Material and methods}

\section{Anuran collection and morphological analysis}

In February 2020, one female anuran, E. cesarii measuring $39 \mathrm{~mm}$ snout-vent length and weight of $5.8 \mathrm{~g}$, was captured for a major project of biodiversity of parasites in amphibians (FAPESP 2018/096234; FAPESP 2018/00754-9). A new sampling effort was carried out at different times within the major 
project, but it was not successful in collecting more specimens of E. cesarii. The specimen was collected on a dirt road in the municipality of Araguaiana, Mato Grosso State, Brazil (14'35'5.29" S, $\left.51^{\circ} 41^{\prime} 19.15^{\prime \prime} \mathrm{W}\right)$. The host was deposited in the Herpetologica Collection of the Regional University of Ceará (Num. CHUFC A9761).

The anuran was killed using $50 \mathrm{mg} / \mathrm{kg}$ of sodium thiopental (Thiopentax ${ }^{\circledR}$ ), a commercial anesthetic administered intracerebrally, following the guidelines of Sebben (2007) and the Animal Use Ethics Committee (IBAMA license 60640-1; CEUA-UNESP 1061). The coelom was opened via a midventral longitudinal incision and the gall bladder was examined for cysts or signs of myxosporean infection. Gallbladder contents were removed by puncturing the bladder wall and pipetting out the contents (Hartigan et al. 2016). The fresh smears containing pseudoplasmodia were evaluated with a differential interference contrast microscope (Leica DMLB 5000, Leica Microsystems, Wetzlar, Germany) at $1000 \times$ magnification. The morphological measurements of myxospores freshly preserved followed the recommendations of Lom \& Arthur (1989). Measurements of 30 myxospores were obtained and presented as mean \pm standard deviation.

\section{Molecular analysis}

Two pseudoplasmodia from the gallbladder were fixed in absolute ethanol and used for the molecular analyses. The access to the genetic data was authorized by the Brazilian Ministry of Environment (Sisgen AA4666FA). The two isolated pseudoplasmodia were collected from the bile material with finetipped sterile needles. DNA isolation was carried out following the animal tissue protocol of the DNeasy Blood \& Tissue Kit (Qiagen, Valencia, CA, USA). The partial SSU rDNA gene was amplified with PCR using general eukaryotic and myxozoan primers (Table 1).

Amplification was performed in a Bio-Rad Mycycler (Bio-Rad Laboratories Pty Ltd., Gladesville, Australia), with initial denaturation at $95^{\circ} \mathrm{C}$ for $3 \mathrm{~min}$, followed by 35 cycles of $95^{\circ} \mathrm{C}$ for $1 \mathrm{~min}, 55^{\circ} \mathrm{C}$ for $45 \mathrm{~s}, 72^{\circ} \mathrm{C}$ for $2 \mathrm{~min}$ and a final extension at $72^{\circ} \mathrm{C}$ for $7 \mathrm{~min}$. PCR reactions were performed in $25 \mu 1$ of solution containing $3 \mu \mathrm{l}$ of extracted DNA and $1 \mu 1$ of each PCR primer at 10 pmol, using PCR Ready-to-Go beads (Pure TaqTMReady-to-GoTM beads, GE Healthcare, Chicago, USA). The solution consisted of stabilizers, BSA, dATP, dCTP, dGTP, dTTP, \pm 2.5 units of puReTaq DNA polymerase and reaction buffer. Each bead was reconstituted to a final volume of $25 \mu \mathrm{l}$. PCR products were analysed by electrophoresis on 1\% agarose gel stained with GelRed and visualised under UV light. The products of the PCR reaction for the SSU rDNA gene were purified and precipitation reaction by Ethanol/EDTA/ Sodium Acetate according to the protocol suggested by the manufacturer was performed, and then sequenced with a BigDye ${ }^{\circledR}$ Terminator ver. 3.1 Cycle Sequencing Kit (Applied). Automatic sequencing by capillary electrophoresis was performed on the ABI3730xl DNA Analyzer (Applied Biosystems).

The partial sequences obtained were assembled and edited using a Sequencher ${ }^{\mathrm{TM}}$ ver. 5.2.4 (Gene Codes, Ann Arbor, MI) to obtain a consensus sequence. The newly generated partial sequences of SSU rDNA were aligned using Geneious ver. 7.1.3 (Kearse et al. 2012) with the ClustalW algorithm (Larkin et al. 2007) and default settings with related genetic sequences that appeared on Blastn search (Table 2). The Bayesian inference (BI) and Maximum-Likelihood (ML) analyses were performed using MrBayes ver. 3.1.2 (Ronquist \& Huelsenbeck 2003) Markov Chain Monte Carlo (MCMC) chains were run for 10 million generations and the log-likelihood scores were plotted. The 'burn-in' was set to $30 \%$. PhyML 3.1 (Guindon et al. 2010) software was used to perform ML analysis, using bootstrap confidence calculated with 1000 replications and GTR $+\mathrm{I}+\mathrm{G}$ evolutionary model which was chosen by jModeltest (Posada 2008) as the best model for this analysis. Phylogenetic trees were generated and edited in FigTree ver. 1.4 (Rambaut 2012). Chloromyxum trilineatum Sekyia, Rosyadi, Zhang \& Sato, 2019 (LC417364) was used as an out group. The aligned sequences of myxosporean parasites were compared using a pair-wise distance (p-distance) matrix (Table 3). 
Table 1. Primers used for the amplification and sequencing of the SSU rDNA of Cystodiscus elachistocleis sp. nov. found parasitizing the gallbladder of Elachistocleis cesarii (Miranda-Ribeiro, 1920) from Araguaiana, Mato Grosso State, Brazil.

\begin{tabular}{lccc}
\hline Primer & Sequence 5'-3' & Paired with & Reference \\
\hline Erib1 & ACCTGGTTGATCCT & Act1r & Barta et al. (1997) \\
Act1r & AATTTCACCTCTCGCTGCCA & Erib1 & Hallett \& Diamant (2001) \\
Myxgen4F & GTGCCTTGAATAAATCAGAG & Erib10 & Diamant et al. (2004) \\
Erib10 & CTTCCGCAGGTTCACCTACGG & Myxgen4F & Barta et al. (1997) \\
MX5 & CTGCGGACGGCTCAGTAAATCAGT & MX3 & Andree et al. (1999) \\
MX3 & CCAGGACATCTTAGGGCATCACAGA & MX5 & Andree et al. (1999) \\
\hline
\end{tabular}

\section{Institutional abbreviations}

INPA = Instituto Nacional de Pesquisas da Amazônia

\section{Results}

\section{Taxonomy}

Phylum Cnidaria Hatschek, 1888

Unranked subphylum Myxozoa Grassé, 1970

Class Myxosporea Bütschli, 1881

Order Bivalvulida Shulman, 1959

Family Myxidiidae Thélohan, 1982

Genus Cystodiscus Lutz, 1889

Cystodiscus elachistocleis sp. nov.

urn:1sid:zoobank.org:act:E2AE8907-E225-4804-A2F9-E3920AD6298D

Figs 1-3

\section{Type host}

Elachistocleis cesarii (Miranda-Ribeiro, 1920).

\section{Site of infection}

Gallbladder.

\section{Etymology}

The species epithet is derived from the genus Elachistocleis of the host.

\section{Material examined}

\section{Hapantotypes}

BRAZIL • 10+ myxospores; Mato Grosso State, Araguaiana municipality; $14^{\circ} 35^{\prime} 5.29^{\prime \prime}$ S, $51^{\circ} 41^{\prime} 19.15^{\prime \prime}$ W; glycerogelatin slide; GenBank MZ645740-MZ645741; INPA79.

\section{Description}

Numerous pseudoplasmodia were found free in the bile. Pseudoplasmodia (Fig. 1C) of approximately $2 \mathrm{~mm}$ were rounded in shape, appeared to be formed by a 'gelatinous' substance, and were floating in the host's bile containing several myxospores in its interior. The morphology of myxospores found 


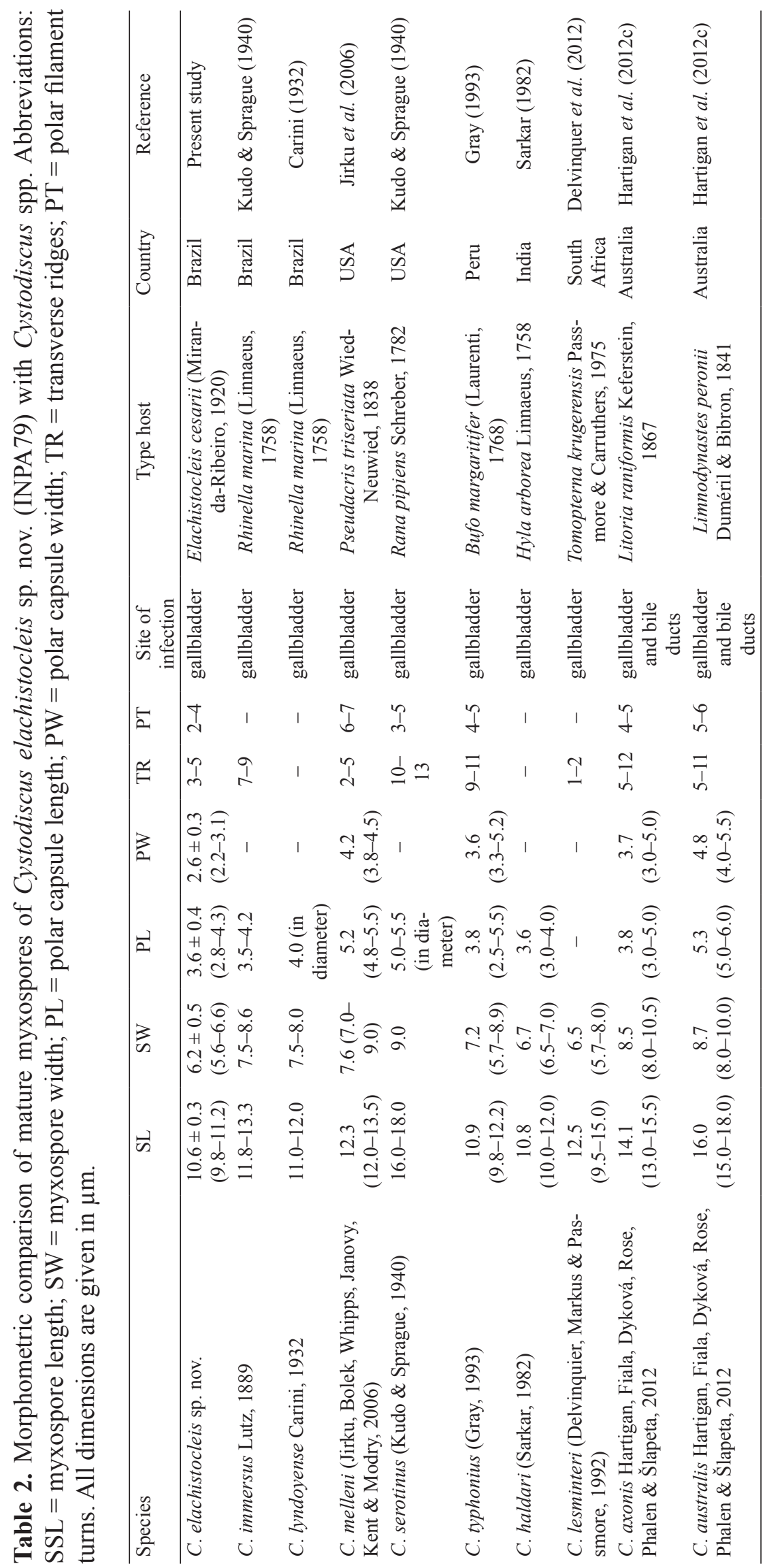


Table 3. The similarity in SSU rDNA sequences of Cystodiscus spp. The upper triangle shows the percentage of nucleotide similarity, while the lower triangle shows the actual nucleotide difference.

\begin{tabular}{llcccccc}
\hline \multicolumn{1}{c}{ Host isolate } & 1 & 2 & 3 & 4 & 5 & 6 \\
\hline 1 & Cystodiscus elachistocleis sp. nov. MZ645740 & & 97.3 & 94.1 & 94.9 & 94.0 & 91.4 \\
2 & Cystodiscus cf. immersus HQ822162 & 24 & & 95.1 & 96.2 & 94.9 & 93.0 \\
3 & Cystodiscus cf. immersus 2 HQ822159 & 52 & 43 & & 84.6 & 93.8 & 91.4 \\
4 & Cystodiscus melleni DQ003031 & 89 & 34 & 48 & & 93.1 & 92.3 \\
5 & Cystodiscus australis HQ822149 & 53 & 45 & 55 & 61 & & 91.0 \\
6 & Cystodiscus axonis HQ822165 & 76 & 62 & 76 & 68 & 80 & \\
\hline
\end{tabular}

in the gallbaldder of E. cesarii corresponded to the genus Cystodiscus. The myxospores (Figs 1A-B, 2) were ellipsoid to ovoid. The two myxospore valves were joined by a raised ridge that appeared straight or slightly curved (S-shaped in sutural view) along the medial axis of the myxospore. Transverse depressions on the surface of the myxospores appeared connected to the sutural ridge depression. Their measurements presented as mean $\pm \mathrm{SD}$ (range) were: myxospore length $10.6 \pm 0.3(9.8-11.2) \mu \mathrm{m}$, myxospore width $6.2 \pm 0.5(5.6-6.6) \mu \mathrm{m}$. The polar capsules were pyriform and equal in size, situated each one in a myxospore extremity and measured $3.6 \pm 0.4(2.8-4.3) \mu \mathrm{m}$ in length and $2.6 \pm 0.3(2.2-$ 3.1) $\mu \mathrm{m}$ in width. The polar filament present within the polar capsule had $2-4$ coils. The myxospores showed 3-5 transverse ridges and a binucleated sporoplasm. Filiform polar appendages were not observed.

\section{Remarks}

Cystodiscus elachistocleis sp. nov. was morphometrically compared to all Cystodiscus spp. described worldwide (Table 2). The species that most resembled C. elachistocleis sp. nov. was C. haldari (Sarkar, 1982), which showed similarity in all measurements available for comparison. However, the geographical distance (Brazil vs India) and the different type host (E. cesarii vs Hyla arborea (Linnaeus, 1758)) allow us to separate the two species. Furthermore, $C$. haldari does not present any comparative values such as the number of turns of the polar filament and the number of transverse ridges, which could differentiate the two species. Cystodiscus thyponius Gray (1993) also presented measures of length and width of myxospores similar to those found in $C$. elachistocleis sp. nov. However, differences were observed in the polar capsule width $(2.6 \pm 0.3(2.2-3.1)$ vs $3.6(3.3-5.2))$ and the number of transverse ridges (3-5 vs 9-11).

Regarding the Cystodiscus spp. described from Brazil, C. elachistocleis sp. nov. was morphometrically compared with two species parasitizing the gallbladder of Rhinella marina (Linnaeus, 1758). Cystodiscus immersus, Kudo \& Sprague (1940) presented a longer body length than that found in C. elachistocleis sp. nov. (11.8-13.3 vs $10.6 \pm 0.3(9.8-11.2)$ ), in addition to a greater number of transverse ridges (7-9 vs 3-5). Cystodiscus lyndoyense Carini, 1932 showed the length of the body (11.0-12.0 vs $10.6 \pm 0.3$ (9.8$11.2)$ ) and the body width (7.5-8.0 vs $6.2 \pm 0.5$ (5.6-6.6)) longer than that found for $C$. elachistocleis sp. nov. The other Cystodiscus spp. already described presented a body length longer than that observed in C. elachistocleis sp. nov.

\section{Molecular analyses}

Fragments of 1730-bp and 1916-bp of the SSU rDNA gene were generated. The fragments showed $100 \%$ similarity when aligned. The BLAST search of the sequences did not reveal a direct match with myxozoan sequences available in GenBank. The genetically closest species was $C$. immersus, which exhibited a similarity of $97.3 \%$, and a difference of 24 out of 885 nucleotides (Table 3). 
A well-supported phylogenetic tree divided into three main groups was obtained (Fig. 3). A monophyletic group composed of Sphaeromyxa Thélohan, 1892 spp. that parasitizes fish, a polyphyletic group composed of Zschokkella Auerbach, 1909 and Myxidium Bütschli, 1882 spp. that infect fish, and
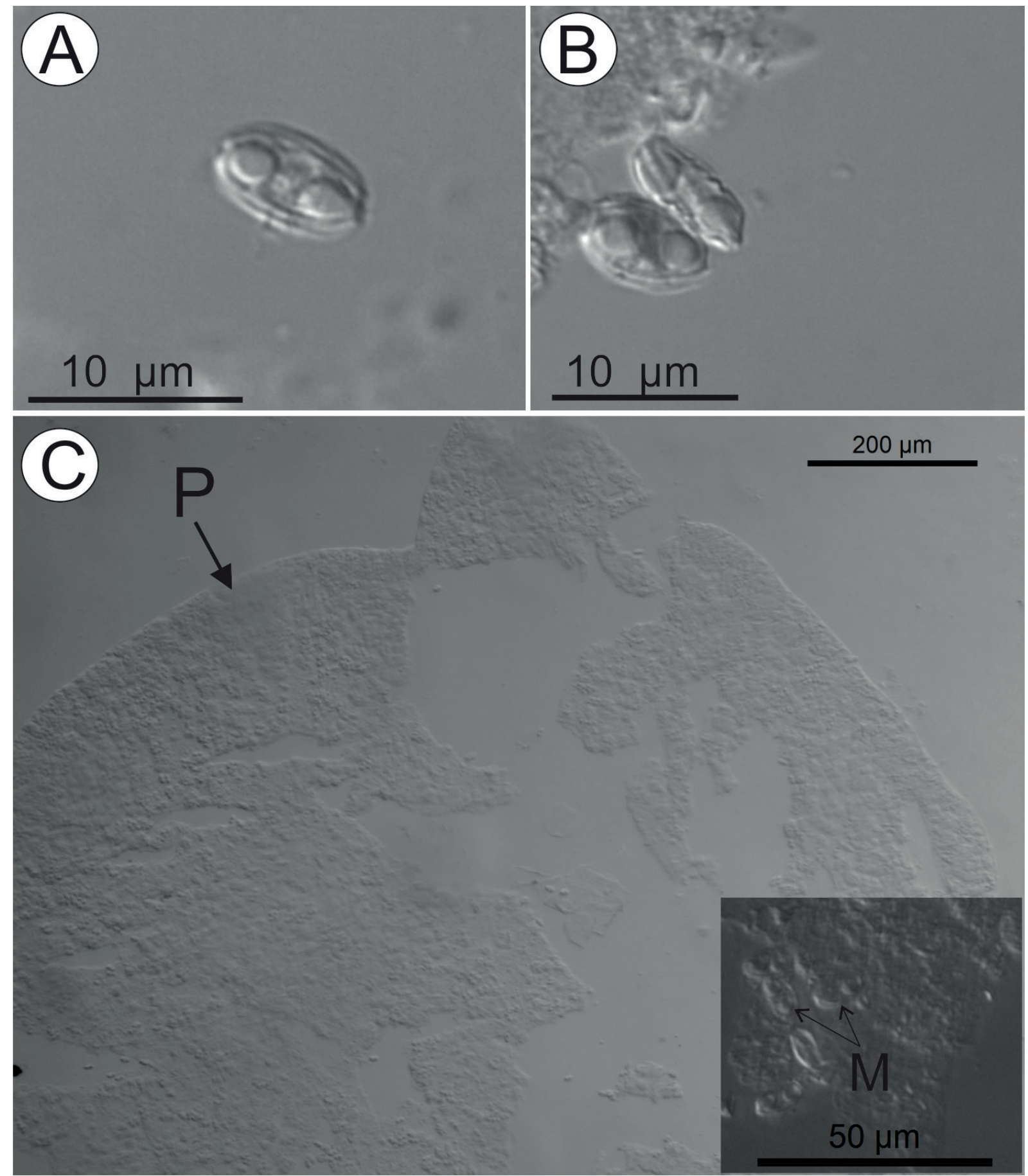

Fig. 1. Myxospores and pseudoplasmodia of Cystodiscus elachistocleis sp. nov. (INPA79) found parasitizing the gallbladder of Elachistocleis cesarii (Miranda-Ribeiro, 1920) from Araguaiana, Mato Grosso State, Brazil. A. Front view of C. elachistocleis sp. nov. B. Front and side view of C. elachistocleis sp. nov. C. Pseudoplasmodium (P) containing several myxospores of C. elachistocleis sp. nov. highlights myxospores $(\mathrm{M})$ through the pseudoplasmodium-forming tissue. 
finally a monophyletic group composed of Cystodiscus spp. that parasitize amphibians. Still, there is a small monophyletic group composed of Myxidium ssp. found in reptiles, fish, and birds. Cystodiscus elachistocleis sp. nov. appears as a sister species of Cystodiscus cf. immersus 1, in a subclade formed by species that parasitize the amphibians gallbladder.

\section{Discussion}

Considering the myxospore morphology, the morphometric data, and SSU rDNA gene partial sequence obtained in the present study, we described C. elachistocleis sp. nov. This finding contributes to our knowledge of the biodiversity of Cystodiscus in amphibians from Brazil. To our knowledge, $C$. elachistocleis sp. nov. is the first record of a myxozoan species parasitizing $E$. cesarii and the third species of Cystodiscus described from Brazil.

Brazil is one of the most species-rich areas for amphibians globally (Segalla et al. 2017). However, amphibians are also considered the most threatened vertebrate group with many species facing extinction (Wake \& Vredenburg 2008; Rebouças et al. 2021). Amphibians also are hosts of a variety of endoparasites and ectoparasites, which in some cases influence their fitness, behavior, feeding, reproduction, and fertility (Barta \& Desser 1984; Lainson et al. 2003; Muñoz-Leal et al. 2017). For this study, only one specimen of E. cesarii was collected despite the extensive sampling effort performed. This could be due to the low presence of the host at the collection site or its ecology, which makes collecting it more difficult than other species. Despite this, several studies describe new myxozoans from a single infected host (Hartigan et al. 2012a; Chen et al. 2020; Mathews et al. 2021).

Regarding myxozoan parasites, there are only two species of Cystodiscus described on Brazilian anurans, $C$. immersus, and C. lyndoyense. However, the morphological and morphometric data differ from the species in the present study. The specificity and the host organ combined with myxospore morphology and molecular data are essential for a determination of a new myxozoan species. Following this taxonomic strategy, we described a new species of Cystodiscus, a gallbladder parasite of E. cesarii.

The phylogenetic analysis performed here supports previous work that suggests that Cystodiscus are amphibian gallbladder species (Hartigan et al. 2012a). The monophyletic subclade composed of Cystodiscus spp. was well supported. The low values of posterior probability found in some nodes within the subclade can be explained by the low number of described species that have their partial
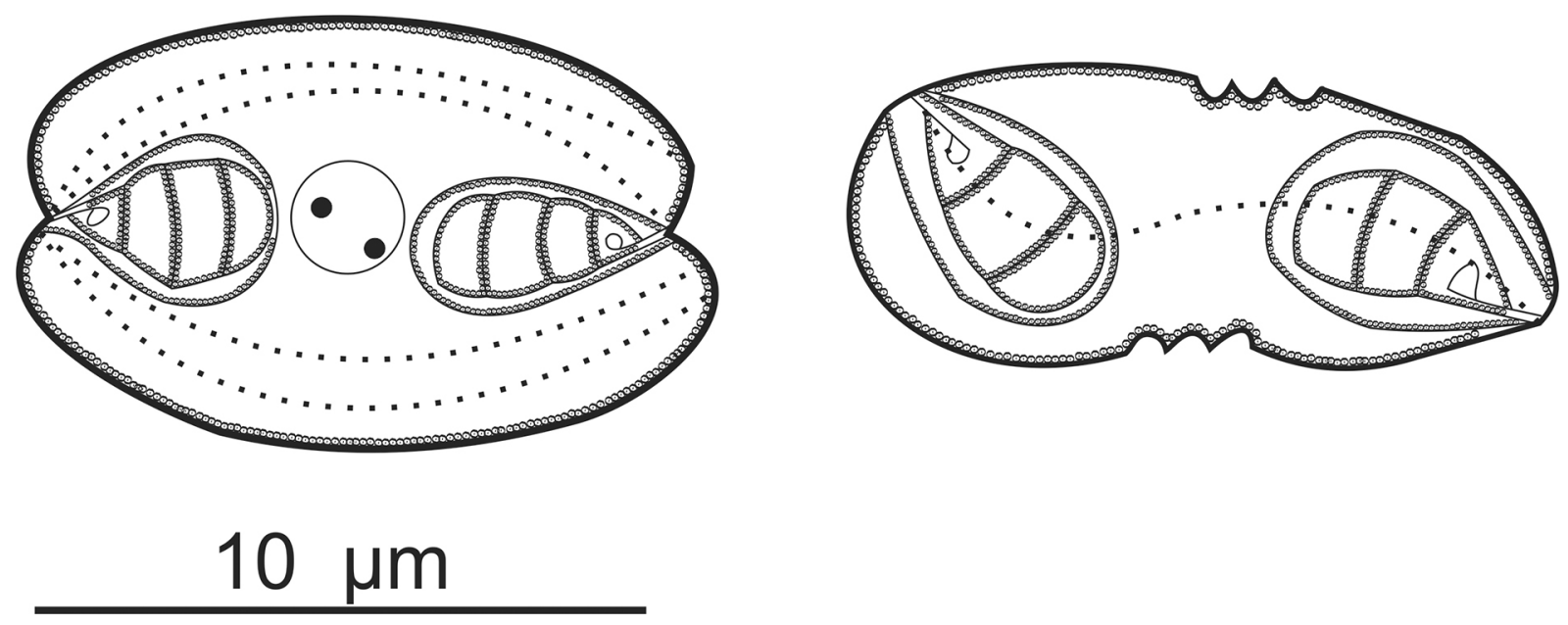

Fig. 2. Schematic drawing of Cystodiscus elachistocleis sp. nov. (INPA79) found parasitizing the gallbladder of Elachistocleis cesarii (Miranda-Ribeiro, 1920) in front and side view. 
sequences of the SSU rDNA gene available. Cystodiscus cf. immersus 1 and Cystodiscus cf. immersus 2 appear with different sister species in the subclade, indicating that they are two distinct species.

The genus Cystodiscus is globally distributed and may have ecological implications outside of Brazil (Hartigan et al. 2012c). These parasites are associated with inflammation of nervous tissue and hepatic disease in several threatened or common frog species (Hartigan et al. 2012b). Although the situation of $E$. cesarii in the list of endangered species is 'least concern - LC', a parasite that causes serious pathologies in these amphibians could further decrease the population of amphibians in Brazil, something that has been happening gradually (Subirá et al. 2012; Ceballos et al. 2020). Despite this, in the present study, no pathologies were observed in the gallbladder or any other host organ associated with parasitism by Cystodiscus elachistocleis sp. nov.

\section{Acknowledgments}

We are grateful to FAPESP (Fundação de Amparo à Pesquisa do Estado de São Paulo) and FAPEMIG (Fundação de Amparo à Pesquisa do Estado de Minas Gerais) for financial support. R.J. da Silva is supported by FAPESP \#2016/50377-1, CNPq \#309125/2017-0, CNPq-PROTAX \#440496/2015-2. D.H.M.D. Vieira is supported by FAPESP 2019/19060-0. L. Pereira Úngari is supported by FAPESP \#2018/00754-9 and 2018/09623-4. L. O'Dwyer is supported by FAPESP \#2018/09623-4. All applicable international, national, and/or institutional guidelines for the care and use of animals were followed

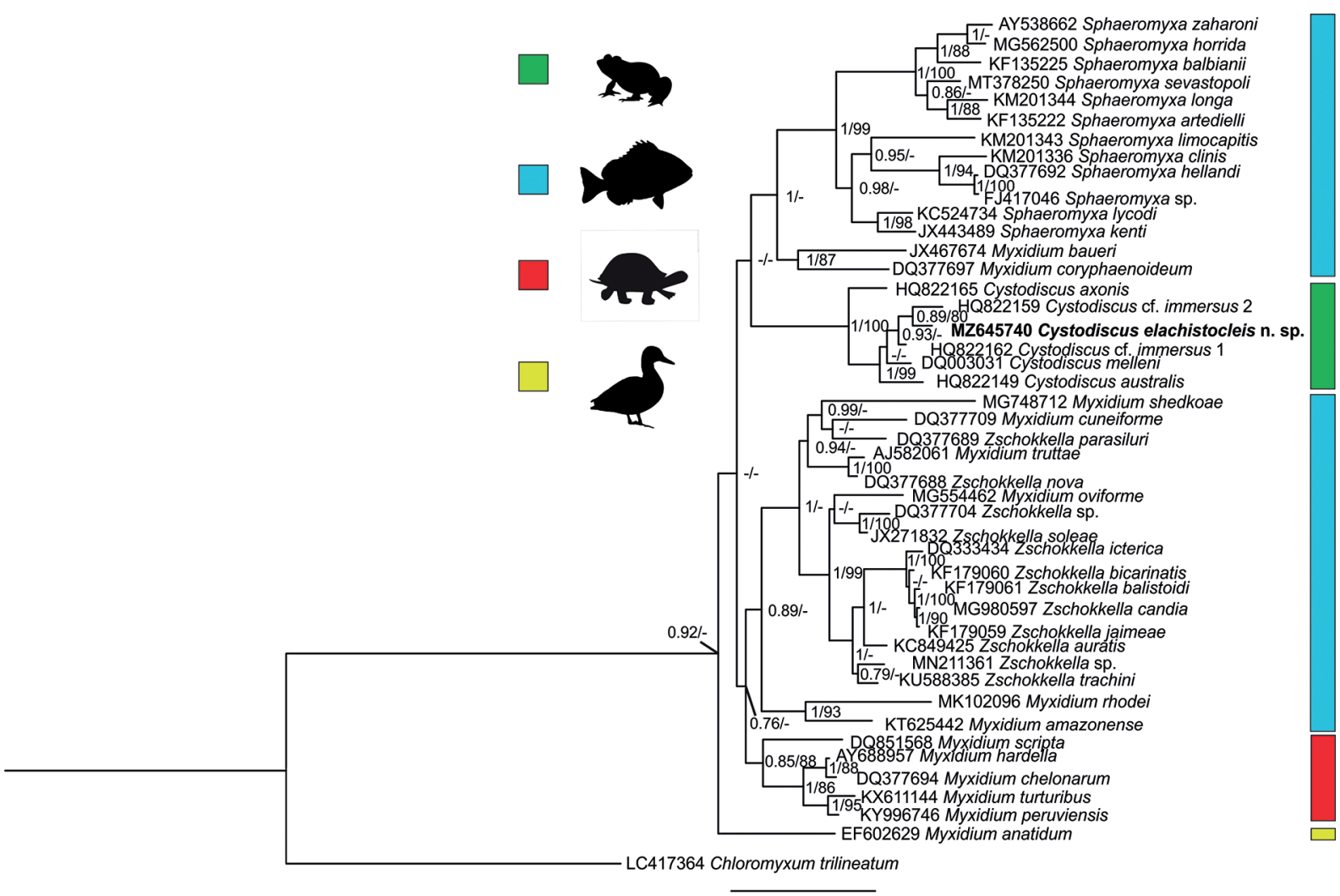

0.3

Fig. 3. Phylogenetic tree of Bayesian analysis based on partial SSU rDNA partial sequences showing the position of Cystodiscus elachistocleis sp. nov. (INPA79) among genetically similar species. Node numbers represent the Bayesian posterior probabilities and bootstrap (BI/ML). Values less than 0.7 are represented by dashes. The scale bar represents the number of substitutions per site. 
(IBAMA license 60640-1; CEUA-UNESP 1061). We thank the non-governmental organization for the preservation of wild animals in Brazil (ONG PAS) for all the assistance.

\section{References}

Barta J.R. \& Desser S.S. 1984. Blood parasites of amphibians from Algonquin Park, Ontario. Journal of Wildlife Diseases 20 (3): 180-189. https://doi.org/10.7589/0090-3558-20.3.180

Ceballos G., Ehrlich P.R. \& Raven P.H. 2020. Vertebrates on the brink as indicators of biological annihilation and the sixth mass extinction. Proceedings of the National Academy of Sciences 117 (24): 13596-13602. https://doi.org/10.1073/pnas.1922686117

Chen W., Yang C. \& Zhao Y. 2020. Characterization of Myxidium spinibarba sp. nov. (Cnidaria, Myxosporea, Myxidiidae) from Spinibarbus sinensis (Bleeker, 1871) in Chongqing China. Parasitology Research 119 (5): 1485-1491. https://doi.org/10.1007/s00436-020-06644-0

Frost D.R. 2020. Amphibian species of the world: an online reference, version 5.4. Available from http://research.amnh.org/vz/herpetology/amphibia [accessed 07 Feb. 2021].

Hartigan A., Fiala I., Dykova I., Rose K., Phalen D.N. \& Slapeta J. 2012a. New species of Myxosporea from frogs and resurrection of the genus Cystodiscus Lutz, 1889 for species with myxospores in gallbladders of amphibians. Parasitology 139 (4): 478-496.

https://doi.org/10.1017/S0031182011002149

Hartigan A., Peacock L., Rosenwax A., Phalen D.N. \& Slapeta J. 2012b. Emerging myxosporean parasites of Australian frogs take a ride with fresh fruit transport. Parasites \& Vectors 5 (208). https://doi.org/10.1186/1756-3305-5-208

Hartigan A., Dhand N.K., Rose K., Slapeta J. \& Phalen D.N. 2012c. Comparative pathology and ecological implications of two myxosporean parasites in native Australian frogs and the invasive cane toad. PLoS One 7(10): e43780. https://doi.org/10.1371/journal.pone.0043780

Hartigan A., Wilkinson M., Gower D.J., Streicher J.W., Holzer A.S. \& Okamura B. 2016. Myxozoan infections of caecilians demonstrate broad host specificity and indicate a link with human activity. International Journal for Parasitology 46 (5-6): 375-381.

https://doi.org/10.1016/j.ijpara.2016.02.001

Kearse M., Moir R., Wilson A., Stones-Havas S., Cheung M., Sturrock S., Buxton S., Cooper A., Markowitz S. \& Duran C. 2012. Geneious Basic: an integrated and extendable desktop software platform for the organization and analysis of sequence data. Bioinformatics 28 (12): 1647-1649. https://doi.org/10.1093/bioinformatics/bts199

Lainson R., De Souza M.C. \& Franco C.M. 2003. Haematozoan parasites of the lizard Ameiva ameiva (Teiidae) from Amazonian Brazil: a preliminary note. Memórias do Instituto Oswaldo Cruz 98 (8): 1067-1070. https://doi.org/10.1590/S0074-02762003000800016

Larkin M.A., Blackshields G., Brown N.P., Chenna R., McGettigan P.A., McWilliam H., Valentin F., Wallace I.M., Wilm A., Lopez R., Thompson J.D., Gibson T.J. \& Higgins D.G. 2007. Clustal W and Clustal X version 2.0. Bioinformatics 23 (21): 2947-2948.

https://doi.org/10.1093/bioinformatics/btm404

Lom J. \& Arthur J.R. 1989. A guideline for the preparation of species descriptions in Myxosporea. Journal of Fish Diseases 12 (2): 151-156. https://doi.org/10.1111/j.1365-2761.1989.tb00287.x

Lom J. \& Dyková I. 2006. Myxozoan genera: Definition and notes on taxonomy, life-cycle terminology and pathogenic species. Folia Parasitologica 53: 1-36. https://doi.org/10.14411/fp.2006.001 
Lutz A. 1889. Über ein Myxosporidium aus der Gallenblase brasilianischer Batrachier. Centralblatt für Bakteriologie und Parasitenkunde 5: 84-88.

Mathews P.D., Bonillo C., Rabet N., Lord C., Causse R., Keith P. \& Audebert F. 2021. Phylogenetic analysis and characterization of a new parasitic cnidarian (Myxosporea: Myxobolidae) parasitizing skin of the giant mottled eel from the Solomon Islands. Infection, Genetics and Evolution 94: 104986. https://doi.org/10.1016/j.meegid.2021.104986

Muñoz-Leal S., Toledo L.F., Venzal J.M., Marcili A., Martins T.F., Acosta I.C.L., Pinter A. \& Labruna M.B. 2017. Description of a new soft tick species (Acari: Argasidae: Ornithodoros) associated with stream-breeding frogs (Anura: Cycloramphidae: Cycloramphus) in Brazil. Ticks and Tick-Borne Diseases 8 (5): 682-692. https://doi.org/10.1016/j.ttbdis.2017.04.015

Peloso P.L. V, Sturaro M.J., Forlani M.C., Gaucher P., Motta A.P. \& Wheeler W.C. 2014. Phylogeny, taxonomic revision, and character evolution of the genera Chiasmocleis and Syncope (Anura, Microhylidae) in Amazonia, with descriptions of three new species. Bulletin of the American Museum of Natural History 2014 (386): 1-112. https://doi.org/10.1206/834.1

Rambaut A. 2012. FigTree v1.4. Available from http://tree.bio.ed.ac.uk/software/figtree [accessed 7 Feb. 2021].

Rebouças R., Dos Santos M.M., Martins A.G.S., Domingos A.H.R., Santos I. \& Toledo L.F. 2021. Warming drives cryptic declines of amphibians in eastern Brazil. Biological Conservation 256: 109035. https://doi.org/10.1016/j.biocon.2021.109035

Ronquist F. \& Huelsenbeck J.P. 2003. MrBayes 3: Bayesian phylogenetic inference under mixed models. Bioinformatics 19 (12): 1572-1574. https://doi.org/10.1093/bioinformatics/btg180

de Sá R.O., Streicher J.W., Sekonyela R., Forlani M.C., Loader S.P., Greenbaum E., Richards S. \& Haddad C.F.B. 2012. Molecular phylogeny of microhylid frogs (Anura: Microhylidae) with emphasis on relationships among New World genera. BMC Evolutionary Biology 12 (1): 1-21.

https://doi.org/10.1186/1471-2148-12-241

Sánchez-Nivicela J.C., Peloso P.L., Urgiles V.L., Yánez-Muñoz M.H., Sagredo Y., Páez N. \& Ron S. 2020. Description and phylogenetic relationships of a new trans-Andean species of Elachistocleis Parker 1927 (Amphibia, Anura, Microhylidae). Zootaxa 4779 (3): 323-340.

https://doi.org/10.11646/zootaxa.4779.3.2

Sebben A. 2007. Microdissecação fisiológica a fresco: uma nova visão sobre a anatomia de anfíbios e répteis. Herpetologia no Brasil 2: 311-325.

Segalla M.V., Caramaschi U., Cruz C.A.G., Grant T., Haddad C.F.B., Garcia P.C.A., Berneck B.V.M. \& Langone J.A. 2017. Brazilian amphibians: list of species. Herpetologia Brasileira 5: 34-46.

Subirá R.J., de Souza E.C.F., Guidorizzi C.E., de Almeida M.P., de Almeida J.B. \& dos Santos Martins D. 2012. Avaliação científica do risco de extinção da fauna brasileira - resultados alcançados em 2012. Biodiversidade Brasileira-BioBrasil (2): 124-130.

Toledo L.F., Loebmann D. \& Haddad C.F.B. 2010. Revalidation and redescription of Elachistocleis cesarii (Miranda-Ribeiro, 1920) (Anura: Microhylidae). Zootaxa 2418 (1): 50-60.

Wake D.B. \& Vredenburg V.T. 2008. Are we in the midst of the sixth mass extinction? A view from the world of amphibians. Proceedings of the National Academy of Sciences 105 (Supplement 1): 1146611473. https://doi.org/10.1073/pnas.0801921105 
Manuscript received: 7 February 2021

Manuscript accepted: 21 September 2021

Published on: 21 October 2021

Topic editor: Rudy Jocqué

Desk editor: Eva-Maria Levermann

Printed versions of all papers are also deposited in the libraries of the institutes that are members of the EJT consortium: Muséum national d'histoire naturelle, Paris, France; Meise Botanic Garden, Belgium; Royal Museum for Central Africa, Tervuren, Belgium; Royal Belgian Institute of Natural Sciences, Brussels, Belgium; Natural History Museum of Denmark, Copenhagen, Denmark; Naturalis Biodiversity Center, Leiden, the Netherlands; Museo Nacional de Ciencias Naturales-CSIC, Madrid, Spain; Real Jardín Botánico de Madrid CSIC, Spain; Zoological Research Museum Alexander Koenig, Bonn, Germany; National Museum, Prague, Czech Republic. 